\title{
UVODNIK
}

\section{OB STOTI OBLETNICI ZAČETKA PRVE SVETOVNE VOJNE - ALI SMO SE IZ KONFLIKTOV V ZADNJIH STO LETIH KAJ NAUČILI?}

Tak je naslov tokratne tematske številke, s katero smo želeli poudariti pomembno obletnico. Naš namen ni bil izdati številke na temo vojaške zgodovine, saj je naslov publikacije vendarle Sodobni vojaški izzivi. Kljub temu se nekaterim zgodovinskim temam in dejstvom nismo izognili. Brez proučevanja in predstavitve vsebinskega okvira ne bi mogli ugotavljati, ali smo se iz konfliktov v zadnjih sto letih kaj naučili.

Gre za dolgo in dinamično stoletje. Veliko je bilo napisanega o tem obdobju, še posebno z varnostnega in vojaškoobrambnega vidika. Prva in druga svetovna vojna sta bili zelo obsežni. Dosegli sta nepričakovane razsežnosti v političnem, varnostnem, obrambnem, ekonomskem, družbenem, geografskem in geopolitičnem smislu. Zaznamovali pa sta ga še dve drugi vojni, hladna vojna in vojna proti terorizmu. Ta je sčasoma prešla v boj proti terorizmu, v Sloveniji pa smo dosegli dogovor, da gre na tem področju za zoperstavljanje terorizmu.

Na naštete vojne so pomembno vplivali razvoj tehnologije, informatike, gradbeništva, logistike, inženirstva, letalstva, oborožitve, transporta in še bi lahko naštevali.

Veliko zanimivih posameznikov je vplivalo na razvoj dogodkov v tem obdobju. Vse se je začelo z Gavrilom Principom, ki je usodne nedelje 28. junija 1914 streljal na prestolonaslednika Franca Ferdinanda, Avstro-Ogrska pa se je zato pozneje odločila napasti Srbijo. Veliko imen se je nanizalo na časovni trak zgodovine, nekatera $\mathrm{s}$ pozitivnim, druga z negativnim predznakom. Slovence na tisti čas zagotovo najbolj spomni prvi slovenski general Rudolf Maister, čeprav nekatere generacije v šolah zanj še nikoli niso slišale. Časi se spreminjajo, prav tako naš pogled na zgodovinske spomine in dejstva. Zato je prav, da se nekaterih stvari, oseb in dogodkov spominjamo, jih analiziramo, ovrednotimo, vse zato, da bi se iz njih kaj naučili. Predvsem pa, da ne bi ponavljali vsega tistega, kar je zgodovina pokazala, da je bilo narobe, slabo, škodljivo za posameznika, narode, naravo, države ali svet. 
Na naše vprašanje, ali smo se v zadnjih sto letih kaj naučili, je Uroš Tovornik odgovoril s prispevkom z naslovom Čas oblikovanja novega svetovnega reda, $\mathrm{v}$ katerem trdi, da današnji varnostni problemi večinoma izvirajo iz odločitev, sprejetih na versajski mirovni konferenci, in iz poznejših dogodkov. Avtor v sklepu povzame, da je današnja geopolitična situacija bistveno drugačna od tiste pred sto leti ali pa ji je po drugi strani zelo podobna.

Valerija Bernik se je posvetila temi Kemično orožje-posebnost prve svetovne vojne ali še danes preteča nevarnost. V prispevku predstavi zgodovino uporabe različnih vrst kemičnega orožja, ki so ga sicer prvič preizkusili že avstro-ogrski vojaki na soški fronti v boju z italijanskimi nasprotniki. V nadaljevanju predstavi vse napore mednarodne skupnosti za preprečevanje, omejevanje in zaščito proti kemičnemu orožju.

Danes si je težko predstavljati, da bi kdo od Slovencev šel prostovoljno v vojno daleč stran od svoje domovine in se boril v pokrajini, ki leži na meji med Romunijo in Bolgarijo. O tej posebnosti piše Jože Rozman v prispevku Vojaškogeografska razsežnost Dobrudže in slovenski prostovoljci na tem bojišču v prvi svetovni vojni. Nekoč ozemlje hudih bojev je danes pomembno območje za zavezniške sile, ki rešujejo krizo v Ukrajini.

Mircea Tănase se je posvetil operaciji »Market garden« - junaštvu in tragediji zavezniških padalskih enot na Nizozemskem. Podrobno predstavi in analizira operacijo, ugotavlja, kaj je šlo po načrtih in kaj narobe, na koncu pa poudarja pomen obveščevalne dejavnosti za sedanjost in prihodnost.

Viktor Potočnik je napisal prispevek Obseg in karakter Slovenske vojske. Veliko se je pisalo splošnega o tem, koliko pripadnikov in kakšne enote naj ima Slovenska vojska. Avtor v prispevku pove po resnici. Njegov pregled in izračun sta zelo preprosta in jasna. Je med bralci kdo, ki se z njim ne strinja in je pripravljen to napisati?

Tanja Kremžar Kovač v prispevku z naslovom Vojaškomedicinska obveščevalna dejavnost z omejenimi viri na primeru majhnih držav ugotavlja, da gre pri tej podzvrsti obveščevalno-varnostne dejavnosti za pridobivanje podatkov o zdravstvenih in okoljskih nevarnostih ter o zdravstvenih zmogljivostih in sposobnostih na mednarodnem območju, kjer delujejo pripadniki oboroženih sil. Zakaj je tema pomembna in kako poteka v praksi, je opisala tudi iz svojih izkušenj.

Maja Garb je na podlagi prebranega dela Thomasa R. Mockaitisa Soldiers of Misfortune? napisala recenzijo $\mathrm{z}$ naslovom Problemi vojaško-varnostnega pogodbeništva v Iraku in Afganistanu.

S to številko končujemo leto pomembnih obletnic, kot smo poimenovali leto $2014 \mathrm{v}$ začetku in vabimo k pisanju in branju tem, ki smo jih razpisali za leto 2015 na naši spletni strani http://www.slovenskavojska.si/publikacije/sodobni-vojaski-izzivi/. 